\title{
Acute posterolateral myocardial infarction diagnosed on contrast enhanced CT
}

\author{
Jessica Rose McQuillian, ${ }^{1}$ Anna Kate Barton, ${ }^{2}$ Allister Hargreaves ${ }^{1}$
}

${ }^{1}$ Cardiology, NHS Forth Valley, Stirling, UK

${ }^{2}$ Cardiology, Centre for Cardiovascular Sciences, The University of Edinburgh, Edinburgh, UK

\section{Correspondence to} Dr Jessica Rose McQuillian; j.mcquillian1@nhs.net

Accepted 8 October 2020

\section{Check for updates}

(C) BMJ Publishing Group Limited 2020. No commercial re-use. See rights and permissions. Published by BMJ.

To cite: McQuillian JR, Barton AK, Hargreaves A. BMJ Case Rep 2020;13:e237539. doi:10.1136/bcr-2020-

237539

\section{DESCRIPTION}

A 66-year-old Caucasian woman was admitted to the emergency department at the weekend with sudden onset, central, crushing chest pain of 10/10 severity radiating to her left hand and neck, with associated nausea and vomiting. She reported that it was nothing like she had ever experienced before. She was an active smoker but otherwise her medical history included only hypothyroidism. Her initial ECG showed no changes to suggest myocardial ischaemia (figure 1). Baseline highsensitivity cardiac troponin I (HScTnI) was elevated at $153 \mathrm{ng} / \mathrm{L}(0-16 \mathrm{ng} / \mathrm{L})$.

Pain persisted despite sublingual nitrate and intravenous morphine administration and an intravenous nitrate infusion was commenced. She continued to deteriorate, developing pulmonary oedema and a new oxygen requirement of $15 \mathrm{~L} /$ min. HscTnI at 6 hours was $19810 \mathrm{ng} / \mathrm{L}$. Repeated ECGs failed to demonstrate any changes suggestive of ischaemia asides transient first degree heart block (figure 1). Treatment with dual antiplatelets (aspirin and clopidogrel) and fondaparinux was commenced for presumed non-ST-elevation myocardial infarction (MI). CT scan was performed and reported as showing no evidence of pulmonary embolism or acute aortic syndrome.

Chest pain remained persistent in absence of dynamic ECG change. On cardiology review the following day, CT images were revisited. An acute posterolateral myocardial perfusion defect was noted with preservation of the left ventricular myocardial wall thickness, supportive of a diagnosis of acute MI (figure 2). The patient was transferred to the regional cardiology tertiary centre for coronary angiography. This demonstrated a subtotal occlusion of the proximal left circumflex artery (LCx) which was treated with a drug-eluting stent. She made good clinical progress and was discharged

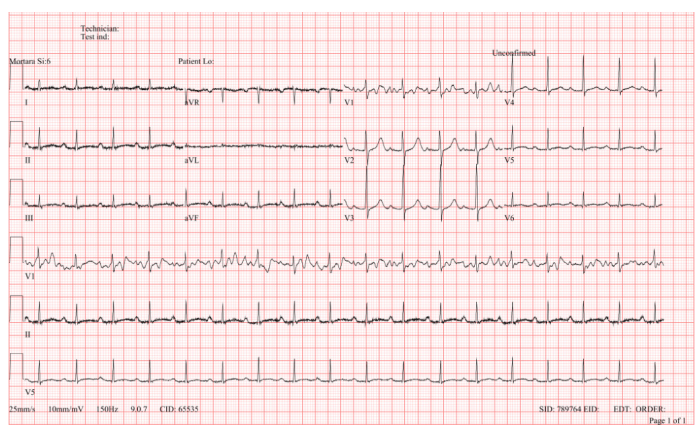

Figure 1 ECG demonstrating borderline first-degree heart block with a PR interval of 223 ms. No ST-segment change suggestive of myocardial ischaemia is evident.

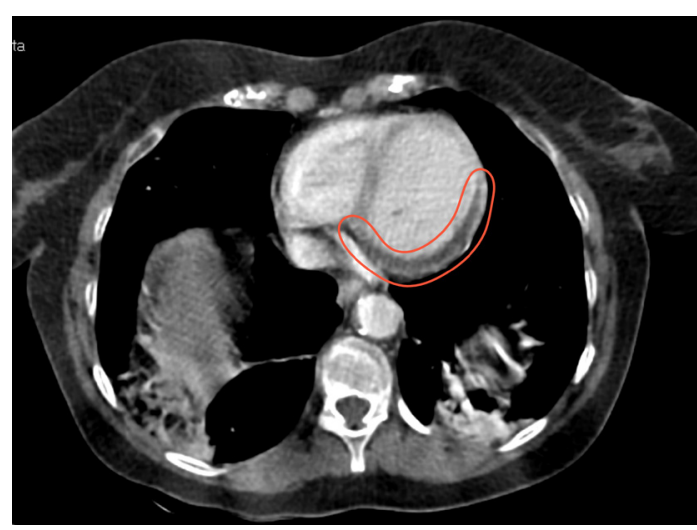

Figure 2 Axial non-contrast CT slice of the mid-thorax demonstrating hypodensity in the posterolateral wall of the left ventricle which is of normal thickness, suggesting acute hypoperfusion. The region of interest has been circled in red.

from the tertiary centre within the following few days. At last follow-up with the cardiac rehabilitation services 2 months after the index event, she remained well and reported good levels of exercise tolerance.

The myocardium should have a homogenous appearance. The displayed image shows and area of decreased enhancement with a darker hue (inferolateral wall: 44 Hounsfield units (low); intraventricular septum: 144 Hounsfield units (normal)) - Multislice CT can detect myocardial perfusion deficit in acute $\mathrm{MI},{ }^{12}$ though not often used clinically for this reason. Notably, in some series, CT has been less sensitive in detecting hypoperfusion in the inferolateral wall compared with other myocardial segments. ${ }^{3}$ However, CT technology continues to advance with more recent data displaying excellent sensitivity for the acute coronary syndrome where classical ECG changes are absent,. ${ }^{4}$

The 12-lead ECG is commonly non-diagnostic in MI caused by a lesion in the LCx artery, ${ }^{5}$ and is regarded the least sensitive in LCx occlusions and infarcts of the interolateral wall compared with MIs in other coronary artery territories,. ${ }^{4}$ Often, as was the case here, an LCX-territory STEMI may present without high lateral ST-elevation. ${ }^{6}$

In the setting of ischaemic acute chest pain without ECG changes where CT thorax is performed to investigate the cause of pain, recognition of an acute myocardial perfusion deficit may help support the diagnosis of acute MI and bolster referral for early coronary angiography.

Twitter Anna Kate Barton @AnnaKateBarton 


\section{Learning points}

- Not all myocardial infarctions (MIs) have typical ischaemic changes on a standard 12-lead ECG. ECG changes are most commonly absent in MI caused by lesions of the left circumflex artery.

- Reduced myocardial perfusion on a non-cardiac CT can help support the diagnosis of MI.

Contributors Drafting the manuscript: JRM. Revising the manuscript critically for important intellectual content: AKB, AH. Approval of the version of the manuscript to be published: all authors.

Funding The authors have not declared a specific grant for this research from any funding agency in the public, commercial or not-for-profit sectors.

Competing interests None declared.

Patient consent for publication Obtained.
Provenance and peer review Not commissioned; externally peer reviewed.

\section{REFERENCES}

1 Mahnken AH, Koos R, Katoh M, et al. Assessment of myocardial viability in reperfused acute myocardial infarction using 16-slice computed tomography in comparison to magnetic resonance imaging. J Am Coll Cardiol 2005;45:2042-7.

2 Rogers IS, Cury RC, Blankstein R, et al. Comparison of postprocessing techniques for the detection of perfusion defects by cardiac computed tomography in patients presenting with acute ST-segment elevation myocardial infarction. J Cardiovasc Comput Tomogr 2010;4:258-66.

3 Masuda Y, Yoshida H, Morooka N, et al. The usefulness of X-ray computed tomography for the diagnosis of myocardial infarction. Circulation 1984;70:217-25.

4 Branch KR, Busey J, Mitsumori LM, et al. Diagnostic performance of resting CT myocardial perfusion in patients with possible acute coronary syndrome. AJR Am J Roentgenol 2013;200:W450-7.

5 Daly MJ, Scott PJ, Harbinson MT, et al. Improving the diagnosis of culprit left circumflex occlusion with acute myocardial infarction in patients with a nondiagnostic 12-lead ECG at presentation: a retrospective cohort study. J Am Heart Assoc 2019;8:e011029.

6 Stribling WK, Abbate A, Kontos M, et al. Myocardial infarctions involving acute left circumflex occlusion: are all occlusions created equally? Interv Cardiol 2010;2:695-704.

Copyright 2020 BMJ Publishing Group. All rights reserved. For permission to reuse any of this content visit

https://www.bmj.com/company/products-services/rights-and-licensing/permissions/

BMJ Case Report Fellows may re-use this article for personal use and teaching without any further permission.

Become a Fellow of BMJ Case Reports today and you can:

- Submit as many cases as you like

- Enjoy fast sympathetic peer review and rapid publication of accepted articles

- Access all the published articles

- Re-use any of the published material for personal use and teaching without further permission

\section{Customer Service}

If you have any further queries about your subscription, please contact our customer services team on +44 (0) 2071111105 or via email at support@bmj.com.

Visit casereports.bmj.com for more articles like this and to become a Fellow 